\title{
Body postures versus production requirements - the case of a fiberglass parts factory
}

\author{
Silva, $\mathrm{V}^{\mathrm{a}}$; Pereira, $\mathrm{B}^{\mathrm{a}}$; Maria, $\mathrm{R}^{\mathrm{b}}$ and Chagas, $\mathrm{T}^{\mathrm{c}}$ \\ ${ }^{a}$ Centro Universitário de Patos de Minas - 808, Major Gote Street - Caiçaras - Patos de Minas - MG - Brazil - \\ Zip Code 38.702-054; e-mails:vivianne@unipam.edu.br and bruno-s-pereira@hotmail.com \\ ${ }^{b}$ Federal Institute of Education, Science and Technology of Minas Gerais - 3007, Michael Pereira de Souza \\ Avenue - Campinho - Congonhas - MG - Brazil-Zip Code: 36.415-000; e-mail: robert.maria@ifmg.edu.br \\ ${ }^{c}$ Federal University of Ouro Preto. School of Minas - Morro do Cruzeiro Campus - Ouro Preto - MG - Brazil - \\ Zip Code: 35.400-000; e-mail: tays_torres@yahoo.com.br
}

\begin{abstract}
This study aimed to perform an ergonomic analysis in a fiberglass parts factory. For this purpose, was used the methodology of Ergonomic Work Analysis (EWA). At the end of the study it was possible to identify some ways to the development of improvements in order to contribute to the transformation of working conditions in the sector analyzed.
\end{abstract}

Keywords: Ergonomics; Analysis; Health

\section{Introduction}

This study presents the result of an ergonomic analysis in a fiberglass parts factory, which the arising demand was analyzing the "incorrect" postures adopted by workers and propose actions in order to improve it. The analysis focused on the parts rolling and finishing by their strict quality requirement which workers are subjected. With such demands and because of the difficulties of carrying out their tasks, workers come up with changes in their physical body arrangement, changing the way they work so as to achieve the results required by the company. According to Lima, (2000) "The stance taken by a worker is never merely the result of personal idiosyncrasies, but it is determined by the complex interplay of multiple constituent factors of the work situation."

\section{Methodology}

The methodology of Ergonomic Work Analysis (EWA) was used, according to Guerin and others, (2001) by means of open and systematic observations, selfconfrontation and semi-structured interviews as a way of characterizing the production process and to propose recommendations that may contribute to the improvement of working conditions, while taking into account the objectives of maintaining the health of workers and the range of productivity and quality expected by the company. The study sample consisted of three employees responsible for the manual process of rolling and finishing of the fiberglass parts.

\section{Results}

The ergonomic analysis of work identified that among the requirements to which workers are submitted to the task of rolling and hand finishing of fiberglass parts are: the demands of visual control 
that allows the perception of irregularities and burrs on the parts that compromise the quality of the final product; constant attention during the execution of the movement due to the working tools used throughout the journey, requiring constant vigilance to avert accidents, beyond the care and attention spent to avoid waste and in order to maintain the quality of the product; the skill, experience and knowledge gained from practice that relate to the cognitive demands required throughout the process to achieve the expected production goals. Added to these requirements, it was still evident through the analysis: that the work is repetitive and somewhat variable and require prolonged static postures, extreme positions of various joints, constant use of force of arms, wrist and hands, trunk postures of constant slope and squatting postures to enter and remain for long periods in larger pieces. The absence of a physical layout and suitable furnishings for performing the activity is evidenced by the presence of drums and boards used as tables and / or benches, as well as cans of chemicals used as seats. Another factor that draws attention is the work environment with poor ventilation, constant use of chemicals and lack of Personal Protective Equipment - PPE and Collective Protection Equipment- CPE. All these factors are mentioned in the literature as risk factors for worker's health, capable of triggering from muscle fatigue or discomfort, even pain and installation of occupational diseases, whether physical or mental.

\section{Discussions}

In order to contribute to the transformation of working conditions in the sector analyzed, it is possible to identify some ways to the development of improvements such as:
1. To provide, guide and encourage the correct use of PPE;

2. Reorganizing the rolling and finishing sectors in order to promote sufficient physical space to perform the activities, favorable environmental conditions and the tables, chairs and tables adaptation in accordance with the anthropometric characteristics of workers in order to offer them comfort and safety;

3. Provide appropriate place for rest and meals outside the workplace, providing breaks during the journey to recover the muscle groups used during the activity, and

4. Provide guidance on health and safety through training about chemicals and work tools used.

Within this perspective, the Ergonomist professional's challenge is to build analysis from the real work evidenced by the operational methods and not only apply unambiguous rules and ready-made formulas that often adopt practices like the idea of "ideal posture at work" without understanding the relationship between worker and work. Despite the apparently conflicting interests between companies and workers, it is possible to set up actions in balance with the perspective of the actual work.

\section{References}

[1] Assunção, Ada Ávila 2002, Gesto Repetitivo, trabalho variável. Fundacentro.

[2] Guérin, F, et al, Compreender o trabalho para transformá-lo: a prática da ergonomia, São Paulo, Edgard Blücher, 2001.

[3] Lima, F.P.A. A ergonomia como instrumento de segurança e melhoria das condições de trabalho. Anais do I Seminário de Segurança do Trabalho e Ergonomia Florestal - ERGOFLOR. Belo Horizonte, June, 2000. 